\title{
A case of strongyloidiasis in pregnancy
}

\section{Madhva Prasad $^{1 *}$, Anahita Chauhan ${ }^{1}$, Sumit Chamariya ${ }^{1}$, Sunil Kuyare ${ }^{2}$, Avani Koticha ${ }^{2}$}

\begin{abstract}
${ }^{1}$ Department of Obstetrics and Gynecology, Seth Gordhandas Sunderdas Medical College and King Edward Memorial Hospital, Mumbai, Maharashtra, India

${ }^{2}$ Department of Microbiology, Seth Gordhandas Sunderdas Medical College and King Edward Memorial Hospital, Mumbai, Maharashtra, India
\end{abstract}

Received: 18 December 2016

Accepted: 31 January 2017

\section{*Correspondence: \\ Dr. Madhva Prasad, \\ E-mail: madhva@gmail.com}

Copyright: ( $\subseteq$ the author(s), publisher and licensee Medip Academy. This is an open-access article distributed under the terms of the Creative Commons Attribution Non-Commercial License, which permits unrestricted non-commercial use, distribution, and reproduction in any medium, provided the original work is properly cited.

\begin{abstract}
Helminthic infections such as Strongyloides stercoralis occurs commonly in immunocompromised states. However, they can rarely occur in normal individuals also. A 23 year old multigravida presented at 39 weeks gestation with watery diarrhoea. She was evaluated and diagnosed of strongyloidiasis. Medical management was given and pregnancy outcome was successful. This case is reported because strongyloidiasis is a rare and underreported occurrence in pregnancy, which can occasionally be fatal.
\end{abstract}

Keywords: Antiparasitic agents, Helminthic infection, Infectious diseases, Pregnancy, Strongyloidiasis

\section{INTRODUCTION}

Strongyloides stercoralis infects an estimated 30-100 million people, with a distribution throughout tropical and subtropical areas. Prevalence in rural areas of southeast Asia is estimated to reach $20 \% .^{1}$ However strongyloidiasis infection is underestimated and often ignored by the medical community. ${ }^{2,3}$

\section{CASE REPORT}

A 23 year old street- dweller, G2P1L1 with 39 weeks' gestation was admitted for safe confinement in view of previous lower segment caesarean section (LSCS) with unsure dates and poor antenatal care.

Examination revealed normal temperature, pulse and blood pressure, unremarkable cardiovascular and respiratory systems. On obstetric examination, the uterus was full-term, with cephalic presentation with regular foetal heart sounds, no uterine activity, healthy Pfannenstiel scar and no scar tenderness. On vaginal examination, cervix was $1 \mathrm{~cm}$ dilated with intact membranes and adequate pelvis.

Patient gave history of four to five episodes of watery diarrhoea since the last 2-3 days, for which stool examination was done; which did not show blood, mucus, pus cells, red cells, epithelial cells or macrophages, but, surprisingly, revealed larvae of Strongyloides stercoralis.

Patient also gave history of persistent cough. She had been previously diagnosed as a case of bronchial asthma, but was non-compliant to medication. Fresh opinion of chest physician was sought and metered dose inhalers of bronchodilator agents (fluticasone propionate $250 \mathrm{mcg}$, salmeterol $25 \mathrm{mcg} / 1 \mathrm{puff})$ were restarted. Sputum examination was negative for acid fast bacilli and culture showed no growth. To rule out hyperinfection syndrome, sputum sample was examined but did not demonstrate larvae of Strongyloides stercoralis. Oral ivermectin 12 mg was given as a single stat dose.

Patient's diarrhoea settled and she went into spontaneous labour 3 days after admission. She underwent LSCS for 
thick meconium stained amniotic fluid and delivered a healthy male of 2.550 kilograms. Repeat stool examination sent on the third postoperative day was within normal limits with no evidence of larvae of strongyloides stercoralis in stools. Postoperative course was uneventful.

\section{DISCUSSION}

The ability to cause "autoinfection", multiply and complete its life cycle within humans, gives it a unique position among helminths. ${ }^{1}$

Though commonly reported in relation to immunosuppressed states like HIV infection, HTLV infection and corticosteroid therapy, it can occur in previously healthy individuals also. ${ }^{4}$ While asymptomatic gastrointestinal infection is the most common phenomenon, many reports of fatal and severe complications such as intestinal obstruction have been reported, even in unsuspected patients. ${ }^{5,6}$ Commonly reported pulmonary co-morbidities include bronchial asthma, hypersensitivity pneumonitis, pulmonary eosinophilia and bronchiectasis, of which this patient had bronchial asthma, though in remission. ${ }^{4,7}$

There are many techniques available to improve the detection of larvae of Strongyloides stercoralis like Baerman technique or koga agar plate culture but the stool routine microscopy still remains the method of diagnosis in most of the settings, as was done in this case. $^{8}$

While there is paucity of literature regarding strongyloidiasis in pregnancy, a few studies have reported the prevalence of parasitic infections among pregnant women by stool examination. ${ }^{9}$ Though an association of low birth weight has been suggested with parasitic zoonoses, it has not been completely established. ${ }^{10}$ Ivermectin, a macrocyclic lactone antibiotic is the most effective agent for management of this infection. ${ }^{4}$ Though it is a potentially foetotoxic and embryotoxic agent, previous reports of its successful use in pregnancy with no adverse feto-maternal effects exist. ${ }^{11}$

Postnatal resolution of excretion of strongyloides in the stools was an expected phenomenon, in coherence with a recently reported prospective study. ${ }^{12}$

Strongyloidiasis in pregnancy cannot be taken lightly, because mortalities are still being reported. ${ }^{13}$

\section{CONCLUSION}

To conclude, the diagnosis in this patient was a purely coincidental one, while requesting a routine stool examination. Strongyloidiasis in pregnancy is a hithertho underreported entity, and it is recommended that all such occurrences be reported. Prospective studies are required in this regard, with the ultimate goal of improving maternal and foetal outcomes.

Funding: No funding sources

Conflict of interest: None declared

Ethical approval: Not required

\section{REFERENCES}

1. Brown M. Monograph on Strongyloides stercoralis. Available from http://www.antimicrobe.org/b123.asp Last accessed on 23rd Apr 2015.

2. Alexander CL, Clutterbuck DJ, Jones B. Strongyloides stercoralis: highlighting an imported case of the neglected parasite. Int J STD AIDS. 2013;24(1):73-4.

3. Montes M, Sawhney C, Barros N. Strongyloides stercoralis: there but not seen. Curr Opin Infect Dis. 2010;23(5):500-4.

4. Nutman TB. Intestinal Nematode Infections: Introduction. In: Longo DL, Kasper DL, Jameson JL, Fauci AS, Hauser SL, Loscalzo J, Eds. Harrison's Principles of Internal Medicine.18th Ed. McGraw-Hill; 2012.

5. Vanuytsel T, Sagaert X, Van Dijck. An unsuspected cause of diarrhea and gastrointestinal bleeding during corticosteroid therapy. Acta Gastroenterol Belg. 2014;77(2):259-61.

6. Vithayasai N, Jennuvat S. Gastrointestinal manifestations in severe strongyloidiasis: report of 3 cases and literature review. Southeast Asian J Trop Med Pub Health. 2010;41(1):22-7.

7. Baron RM, Bartlett JG. Bronchiectasis. . In: Longo DL, Kasper DL, Jameson JL, Fauci AS, Hauser SL, Loscalzo J, Eds. Harrison's Principles of Internal Medicine.18th Ed. McGraw-Hill; 2012.

8. Bisoffi Z, Buonfrate D, Montresor A. Strongyloides stercoralis: a plea for action. PLoS Negl Trop Dis. 2013;7(5):e2214.

9. Villar J, Klebanoff M, Kestler E. The effect on fetal growth of protozoan and helminthic infection during pregnancy. Obstet Gynecol. 1989;74(6):915-20.

10. Fairley JK, Bisanzio D, King CH. Birthweight in offspring of mothers with high prevalence of helminth and malaria infection in coastal Kenya. Am J Trop Med Hyg. 2013; 88(1):48-53.

11. Chippaux JP, Gardon-Wendel N, Gardon J, Ernould JC. Absence of any adverse effect of inadvertent ivermectin treatment during pregnancy. Trans Royal Soc Trop Medi Hygiene. 1993;87:318

12. Schär F, Hattendorf J, Khieu V. Strongyloides stercoralis larvae excretion patterns before and after treatment. Parasitology. 2014;141(7):892-7.

13. Buresch AM, Judge NE, Dayal AK, Garry DJ. A fatal case of strongyloidiasis in pregnancy. Obstet Gynecol. 2015. [Epub ahead of print]. PMID: 2577493.

Cite this article as: Prasad M, Chauhan A, Chamariya S, Kuyare S, Koticha A. A case of strongyloidiasis in pregnancy. Int J Reprod Contracept Obstet Gynecol 2017;6:1130-1. 